\title{
Phoenician amphorae in Cypriot Kingdoms during the Cypro-Archaic and Cypro-Classical Periods: Signs, terms, trade, and questions
}

\section{Christiana Christodoulou}

MA student, University of Cyprus

\begin{abstract}
This paper forms a part of my ongoing MA thesis, which focuses on the Phoenician amphorae recovered on Cyprus from the Cypro-Archaic and Cypro-Classical periods. The primary objective of this thesis is the quantitative and qualitative analysis of the published material of the Phoenician amphorae, but it also aims to contribute to the study of trade relations between Cyprus and the Levant during the Archaic and Classical periods. The continuous trade connections between these two areas dates to the second millennium $\mathrm{BC}$ and can be documented by the pottery imports and exports, and epigraphic evidence (Bikai, 1983; Sznycer, 1984; Bikai, 1987a). These pieces of evidence are discussed in this paper.
\end{abstract}

Key words

Connectivity, Cypro-Archaic, Cypro-Classical, Cyprus, Levantine coast, Phoenician Amphorae.

\section{Introduction}

This MA thesis aims to study the Phoenician amphorae which were recovered in various archaeological sites in Cyprus, from the period of City-Kingdoms (750-310 BC) (Satraki, 2012: 29-30). Consequently, this research attempts to create a corpus of all the published evidence of Phoenician amphorae from Cypriot archaeological sites, to shed more light on different aspects of seaborne trade in the eastern Mediterranean. Through a typological, quantitative and spatial analysis, I hope to understand the exchange patterns between Cyprus and 
Phoenicia during the Cypro-Archaic and Cypro-Classical periods. Moreover, I will clasify the specific types of Phoenician amphorae that were exported to Cyprus, and I will try to refine their typology and chronology, in order to contribute to the study of Phoenician amphorae in Cyprus and the eastern Mediterranean generally.

\section{Interconnections between Cyprus and Phoenicia in the second and first millennia BC}

Phoenicians first began venturing on the Mediterranean Sea during the second millennium BC (Ioannou, 2015: 3). Archaeological remains of Phoenician activity on Cyprus dated from the $12^{\text {th }}-11_{\text {th }}$ centuries BC show the presence of strong Phoenician elements in Cypriote art and culture and prove the interconnections between Cyprus and Phoenicia (Karageorghis, 2005: 31). The first evidence of Phoenician presence was found at Palaepaphos in the western part of Cyprus. This Phoenician evidence appeared in Palaepaphos-Skales from the beginning of the Iron Age (11th century BC) (Bikai, 1987b).

Furthermore, it is widely believed that Phoenicians had settled on the island, specifically at Kition, by the midninth century BC (Gjerstad, 1979: 232-233; Knapp, 2008: 368). The proximity of Cyprus to the Levant ensured trade and contact between the two areas from an early time, as the contacts were usual with other neighboring groups, such as Greeks, Egyptians, Anatolians, etc. in the eastern Mediterranean (Reyes 1994: 21). Cypriots and Phoenicians would also have met elsewhere in the Levant and Egypt (Reyes, 1994: 18). At the beginning of the Cypro-Archaic period, Cypriots and Phoenicians stayed side by side on the island.

\section{Phoenician Amphorae: Typological, Morphological and Chronological aspects}

Among the earliest evidence of the long-distance mercantile exchange of raw materials and luxury commodities in the 'Canaan land' are Canaanite jars from the Late Bronze Age. Canaanite jars were the ancestral type of the Phoenician amphorae and appeared from the second millennium BC (Middle Bronze Age II/Late Bronze Age) (Fig. 1) in the Levant to Punic times in the western Mediterranean (Sagona, 1982: 73; Regev, 2004: 337). During the Iron Age in the Mediterranean, two main types of amphora shapes were distributed: (1) the Greek style, and (2) the Levantine style. Phoenician amphorae have distinctive morphological differences from the Greek ones, which are: (1) the low or non-existent neck, and (2) the vertical loop handles. Some of them have one or no handles on the shoulder (Sagona, 1982: 86; Beetle, 2003: 21) (Fig. 2). Large quantities of Iron Age Phoenician amphorae have been recovered at various sites on Cyprus. The majority of these sites are the necropoleis of each city-kingdom, such as Kition-Bamboula (Hadjisavvas 2012). Consequently, I assume that trade activity between Cyprus and Phoenicia was at its zenith during this period.

Before discussing the different types of Phoenician amphorae, it is good to define what 'amphora' means. Like all ceramic vessels, amphorae are made of clay, an easily accessible and low-cost material throughout the ancient world (Rice, 1987: 207; Demesticha and Knapp, 2016). Amphora, as Whitbread (1995: 31) explains, 'has a very distinguished shape that allowed to us to recognize them from other ceramic vessels'. Moreover, the most common use of this vessel was as a maritime transport container; as a result, their shape was most functional for stowage in ships (Demesticha and Knapp, 2016: 5-6). On land, the distribution of amphorae was more difficult and time-consuming. 
Furthermore, amphorae represent important aspects of the economic history of the Mediterranean, because they were the most common transport and storage containers designed to transfer liquid and solid products in bulk, over long distances in the sea (Hein et al., 2008: 1049). Amphorae were used for packaging agricultural products such as wine, olive oil, etc. According to Virginia Grace (1979: 1), a pioneer in amphora studies, 'Amphorae have three main characteristics in common: a neck or mouth narrow enough to be corked, two opposite vertical handles and a tip or knob base, that functioned as a third handle for their transport'. Virginia Grace did not include vessels with a flat base in this definition. Later, Peacock and Williams (1986: 5) modified her definition and considered flat-based vessels as transport amphorae as well. Many more definitions have been published since then (Demesticha, 2001: 2; Demesticha and Knapp, 2017: 36-43).

Moving to the case study of Phoenician amphorae, the term 'Phoenician amphora' defines the regional production and origin of the type of vessel from Phoenicia, which is the region on the Levantine coast, between the mountains of Lebanon and the Mediterranean Sea. Its north and south boundaries are more or less from Tell Suqas (Shukshu) or Arvad (Ancient Aradus) to Akko (Aubet, 1993: 12-13; Moscati, 1999: 5) (Fig. 3). The Phoenician mainland stretches for 200 kilometers from north to south, and is crossed by numerous small rivers. The highest peak of the Mount Lebanon range is more than 3000 metres above sea level and provides timber used for shipbuilding (Ioannou, 2015: 3).

The first evidence of Phoenician amphorae, dated to the Levantine Iron Age I period (c.1200-900 BC), were recovered on the Levantine coast, Cyprus, and Crete. In the Levantine Iron Age II period (c. 900-700 BC), distribution was wider than during the Iron Age I period. However, evidence was not recovered in mainland Greece until recently (Martin, 2017: 102). Moreover, two main types of amphorae existed in the Iron Age: (1) the rounded, and (2) the elongated versions (Regev, 2004: 340; Martin, 2017: 102) (Fig. 2).

Scholars who examined the Levantine-styled amphorae mentioned them with various 'names', such as jars, amphora, storage jars, transport amphorae, crisp ware, or wasp-like (Sagona, 1982). For instance, the Swedish Cyprus Expedition that conducted extensive excavations on the island did a typological analysis of the main pottery recovered in Cypriot archaeological sites (Winbladh, 2003:13) (Fig. 4). However, some misinterpretations can be distinguished, as transport amphorae, for example, are listed as pithoi. Consequently, one of my thesis objectives is to re-examine the terminology and the descriptions of Phoenician transport amphorae from numerous publications that have used the Swedish Cyprus Expedition's typology extensively. Thus far, more than 250 Phoenician amphorae dated to Cypro-Archaic and Cypro-Classical periods have been found in various sites in Cyprus, including the settlements of Kition and Idalion (Karageorghis, 1985; Hadjicosti, 2016), the necropolis at Kition (Hadjisavvas, 2012), the anchorage at Kioni (Leonard, 1995: 155156), and rural sites such as Panayia Ematousa (Jacobsen, 2006: 311) (Fig. 5).

On some amphorae, Phoenician inscriptions in ink have been found. The majority of them were found between the handles or on the shoulders. These inscriptions mainly referred to the god Baal. Some of these inscriptions referred to the owner of the amphora, and those amphorae might have beenused as votive offerings within chamber tombs (Allan, 2004: 241). 
Moreover, some of the scholars who examined the Phoenician amphorae on the island have argued that Cypriot imitations of Phoenician amphorae existed, but none of these scholars performed fabric analysis on the amphorae, and without this analysis, it is not easy to distinguish the origin of these amphorae (Amiran, 1969; Sagona, 1982; Bikai, 1983: 25; Jacobsen, 2006: 311). In my thesis, I will not include any such analysis, but in the future, it will be necessary, especially for some Phoenician amphorae which have different typological features.

\section{Conclusions}

To conclude, Cyprus was one of the critical geographic areas in the eastern Mediterranean basin as the nearest island to the Levantine coast. The contacts between of these two areas (Cyprus and Phoenicia) are incontrovertible, evidenced not only by the epigraphic materials (Sznycer, 1984: 117 - 121) found at Kition, but also from the archaeological material, including pottery.

Over 250 different types of Phoenician amphorae will be included in this Masters thesis from various archaeological sites in Cyprus. Up to 20 sites will be mentioned (necropoleis, settlements, and anchorages), and most of them are included in the power of each city kingdom's periphery. Large quantities of Phoenician amphorae have been found near coastal city-kingdoms, including Kition, Salamis, and Marion. Fewer Phoenician amphorae have been recovered from inland parts of Cyprus (Tamassos and Ledra).

Finally, Lapethos and Soloi, located at the northern part of Cyprus are not mentioned in this thesis, because the only evidence recovered in these sites date from the Cypro-Geometric and Byzantine periods respectively. The main reason that archaeological evidence from the Cypro-Archaic and Cypro-Classical periods has not been recovered in the northern part of Cyprus is that the archaeological sites dated from these periods have not been accessible since the Turkish invasion in 1974 (Gagniers 1985; Diakou 2019). This is one of the limitations of my master thesis, which might be overcome in the future.

\section{Acknowledgements}

For my first paper publication, I would like to thank the MAGS 2019 committee. I am also grateful to the Honor Frost Foundation for awarding me by the bursary and also for the opportunity to present at the MAGS 2019 and publish my work. Finally, I would like to sincerely thank my MA supervisor, Dr. Stella Demesticha, who is always next to me in this path of Maritime Archaeology.

\section{Reference List}

Allan, R., 2004, An inscribed amphora from Deneia. Report of the Department of Antiquities, Cyprus, 241-243. Amiran, R., 1969, Ancient pottery of the Holy Land: from its beginnings in the Neolithic period to the end of the Iron Age. Massada: Massada Press.

Aubet, E., 1993, The Phoenicians and the West: politics, colonies and trade. New York: Cambridge University Press.

Beetle, E., 2003, Phoenician Amphorae of the Persian Period (539-332 BC). Oxford: Archaeopress. 
Bikai, P., 1983, The Imports from the East, in V. Karageorghis (ed.), Palaepaphos-Skales. An Iron Age Cemetery in Cyprus, 396-405.

Bikai, P., 1987a, The Phoenician pottery of Cyprus. Larnaca: A.G. Leventis Foundation.

Bikai, P., 1987b, Trade networks in the early iron age, in D. Rupp (ed.), Western Cyprus: connections: an archaeological symposium held at Brock University, St. Catharines, Ontario, Canada, March 21-22, 1986, 125128. Goteborg: Astroms.

Bikai, P., 1992, Cyprus and Phoenicia: Literary Evidence for the Early Iron Age, in G. Ioannides (ed), Studies in honour of Vassos Karageorghis, 241-248. Nicosia: Society of Cypriot Studies.

Calvet, Y., 1980, Sur certains rites funeraires a Salamine de Chypre, in M. Yon (ed.), Salamine de Chypre, histoire et archeologie: etat des recherches, 115-121. Paris: Editions du Centre national de la Recherche scientifique.

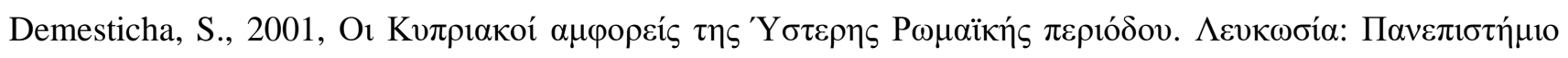
Kú $\operatorname{\rho ov.}$

Demesticha, S. and Knapp, B., 2016, Introduction, in S. Demesticha and B. Knapp (ed.), Maritime transport containers in the Bronze-Iron Age Aegean and Eastern Mediterranean, 2-6. Uppsala: Astroms forlag.

Diakou, S., 2019, The upper Geometric cemetery at Lapithos: University of Pennsylvania Museum Excavations, 1931-1932. Uppsala: Astrom Editions.

Gagniers, J., 1985, Soloi: dix campagnes de fouilles, 1964-1974. Sainte-Foy: Presses de l'Universite Laval. Gjerstad, E., 1960, Pottery Types: Cypro-Geometric to Cypro-Classical. Opuscula Athiensia VII, 105-116.

Gjerstad, E., 1979, The Phoenician colonization and expansion in Cyprus: the pre-Phoenician Kition. Nicosia: Department of Antiquities Cyprus.

Grace, V., 1979, Amphoras and the ancient wine trade. Princeton: American School of Classical Studies at Athens.

Hadjicosti, M., 2016, The Kingdom of Idalion in the Light of New Evidence. Bulletin of the American Schools of Oriental Research 308, 49-63.

Hadjisavvas, S., 2012, The Phoenician period necropolis of Kition. Nicosia: Department of Antiquities Cyprus. Hein, A., Georgopoulou, V., Nodarou, E. and Kilikoglou, V., 2008, Koan amphorae from Halasarna e investigations in a Hellenistic amphora production centre. Journal of Archaeological Science 35, 1049-1061.

Ioannou, C., 2015, Cypriotes and Phoenicians. [Online] Avalable: kyprioscharacter.eie.gr/en/t/Ac. Last accessed 09/05/2019.

Jacobsen, K., 2006, Transport amphorae, in L. Sorensen and K. Jacobsen (eds.), Panayia Ematousa I, 303-336. Aarhus: Aarchus University Press.

Karageorghis, V., 1985, Excavations at Kition. Nicosia: Published for the Republic of Cyprus by the Department of Antiquities.

Karageorghis, V., 2003, The Cyprus collections in the Medelhavsmuseet. Nicosia: The A. G Leventis Foundation. 
Karageorghis, V., 2005, Some aspects of everyday life in Archaic Cyprus, in H. Matthäus and S. Rogge (eds), Cyprus: Religion and Society from the Late Bronze Age to the End of the Archaic Period, 111-125. Shulpat.

Knapp, B., 2008, Prehistoric and protohistoric Cyprus: identity, insularity, and connectivity. Oxford: Oxford University Press.

Leonard, R. J., 1995, The anchorage at Kioni, in J. Fefjer (ed.), Ancient Akamas I. Settlement and environment, 133-156. Aarchus Oakville: Aarhus University Press.

Martin, R., 2017, Iron Age Levant: Background and History of Research, in B. Knapp and S. Demesticha (eds.), Mediterranean Connections: Maritime transport containers and seaborne trade in the Bronze and Iron ages, 102-129. New York: Routledge.

Moscati, S., 1999, The world of the Phoenicians. London: Phoenix Giant.

Peacock, D., and Williams, D., 1986, Amphorae and the Roman economy: an introductory guide. London: Longman.

Regev, D., 2004, The Phoenician Transport Amphora, in J. Eiring and J. Lund (eds.), Transport amphorae and trade in the Eastern Mediterranean: acts of the international colloquium at the Danish Institute at Athens, September 26-29, 2002, 337-352. Aarhus: Aarhus University Press.

Reyes, A., 1994, Archaic Cyprus: a study of the textual and archaeological evidence. Oxford: Clarendon Press. Rice, P., 1987, Pottery Analysis: A sourcebook. Chicago: The University of Chicago Press.

Sagona, A., 1982, Levantine Storage Jars of the 13th to 4th century B.C. Opuscula Athiensia XIV, 73-108.

Sznycer, M., 1984, Inscriptions Pheniciennes sur jarres de la necropole D' Ayios Georghios. Report of the Department of Antiquities, Cyprus, 117-121.

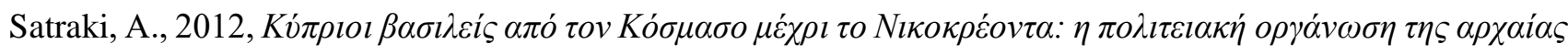

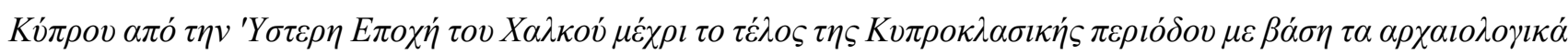

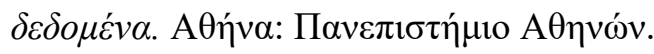

Whitbread, I., 1995, Greek transport amphorae: a petrological and archaeological study. Athens: British School at Athens.

Winbladh, M., 2003, The Cyprus Collections in the Medelhavsmuseet, in V. Karageorghis (ed.), The Cyprus Collections in the Medelhavsmuseet, 13-30. Nicosia: The A. G. Leventis Foundation. 


\section{CHRONOLOGICAL TABLE}

Pre-Neolithic

Neolithic

Chalcolithic

Early Cypriote I

Early Cypriote II

Early Cypriote III

Middle Cypriote I

Middle Cypriote II

Middle Cypriote III

Late Cypriote I

Late Cypriote II

Late Cypriote III

Cypro-Geometric I

Cypro-Geometric II

Cypro-Geometric III

Cypro-Archaic I

Cypro-Archaic II

Cypro-Classical I

Cypro-Classical II

Hellenistic I

Hellenistic II

Roman Period ca. 10,000 B.C. *

8200 - 3900 B.C.

3900 - 2500 B.C.

(Early Bronze Age I)

2500 - 2075 B.C.

(Early Bronze Age II)

(Early Bronze Age III)

(Middle Bronze Age I)

(Middle Bronze Age II)

2075 - 2000 B.C.

2000 - 1900 B.C.*

1900 - 1800 B.C.

1800 - 1725 B.C.

1725 - 1600 B.C.

(Late Bronze Age I)

1600 - 1450 B.C.

(Late Bronze Age II)

1450 - 1200 B.C.

(Late Bronze Age III)

1200 - 1050 B.C.

1050 - 950 B.C.

950 - 900 B.C.

900 - 750 B.C.

750 - 600 B.C.

600 - 480 B.C.

480 - 400 B.C.

400 - 310 B.C.

310 - 150 B.C.

150 - 30 B.C.

30 B.C. - 330 A.D.

Fig. 1: Chronological Table (Karageorghis, 2003: xiii). 

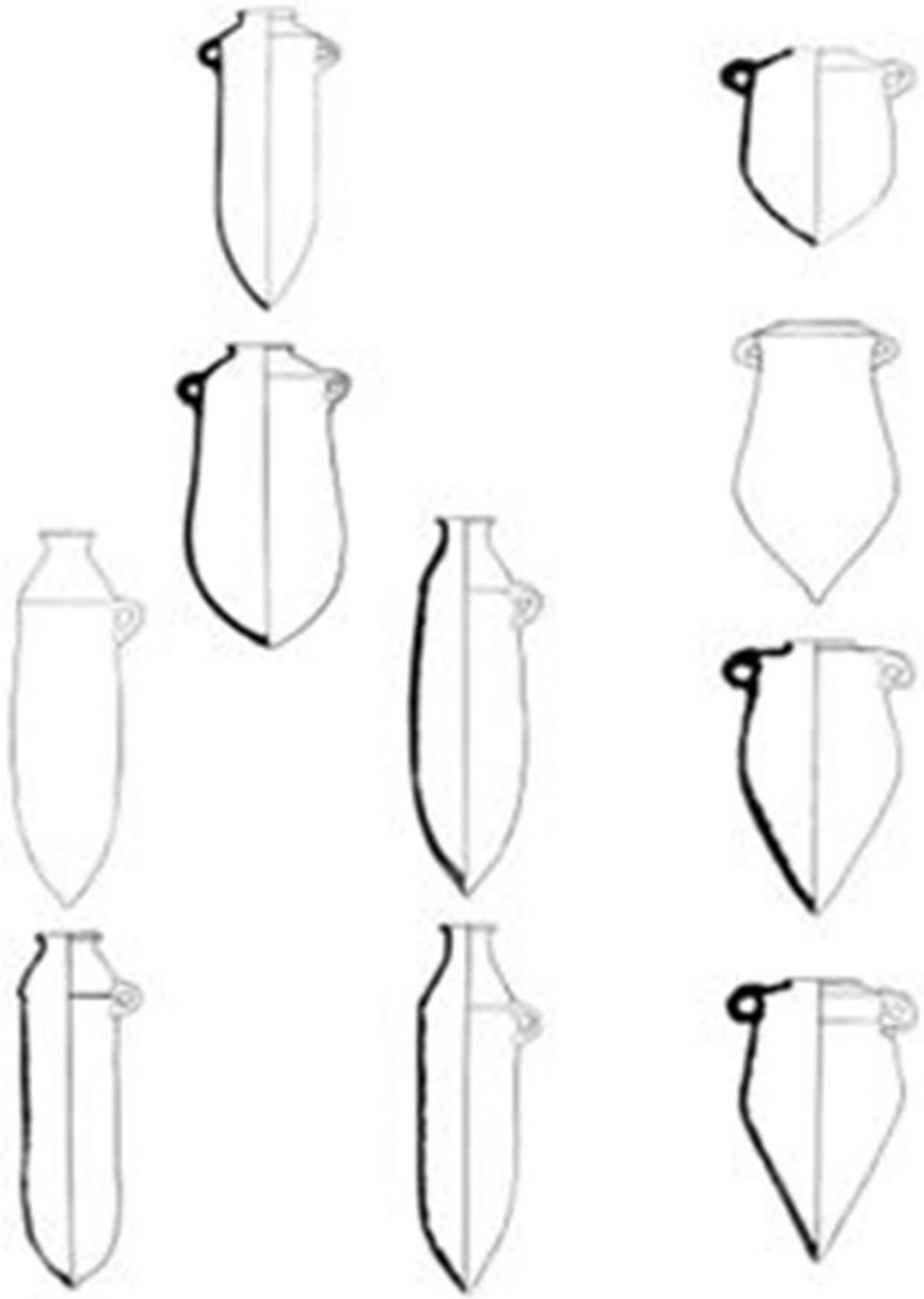

Fig. 2: Various Phoenician types found in Cypriot archaeological sites (Gjerstad, 1960: 112). 


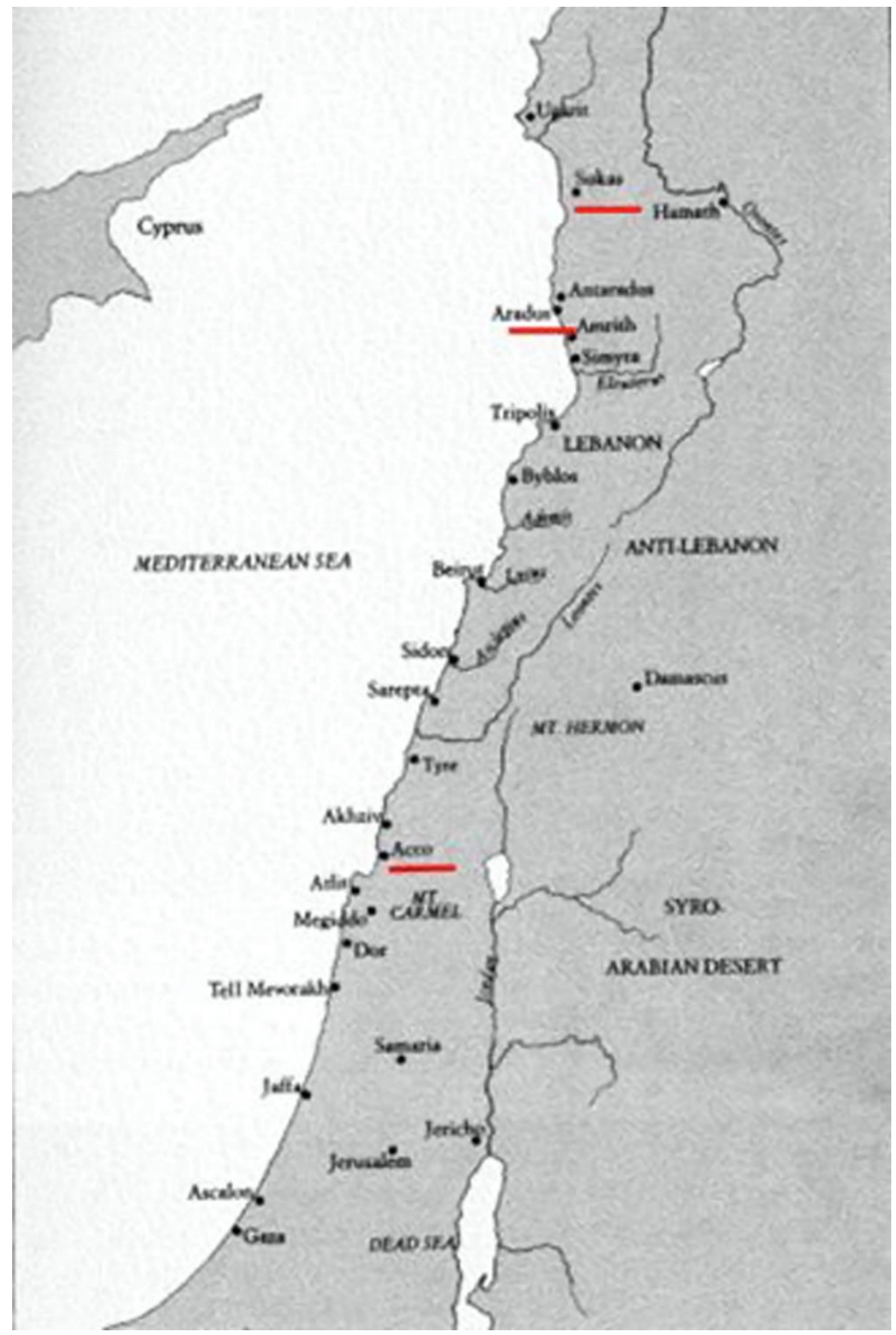

Fig. 3: Phoenicia as S. Moscati and E. Aubet defined its boundaries, according to the archaeological remains (Moscati, 1999: 5). 


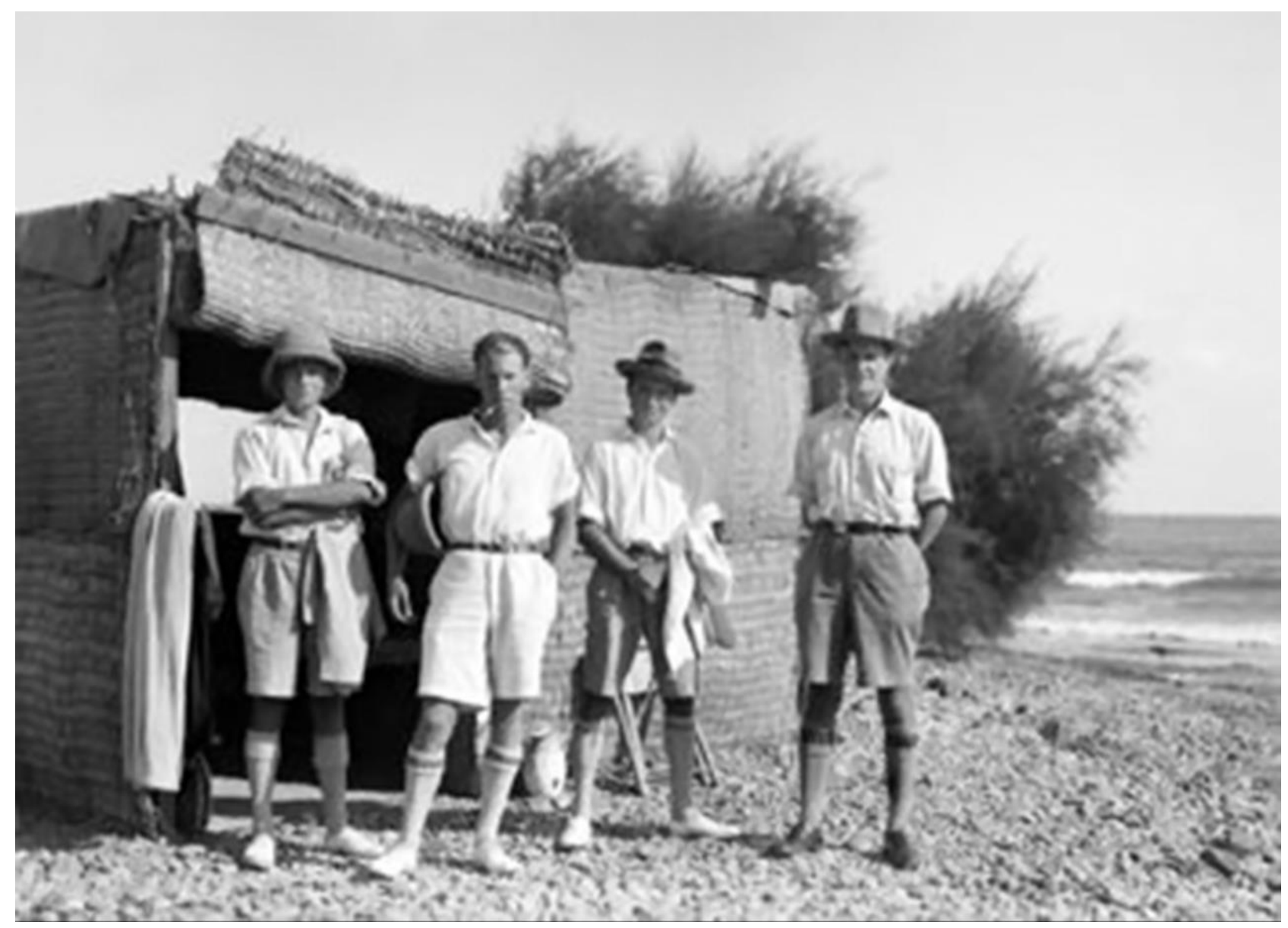

Fig. 4: The four members of the Swedish Cyprus Expedition (Winbladh, 2003: 14).

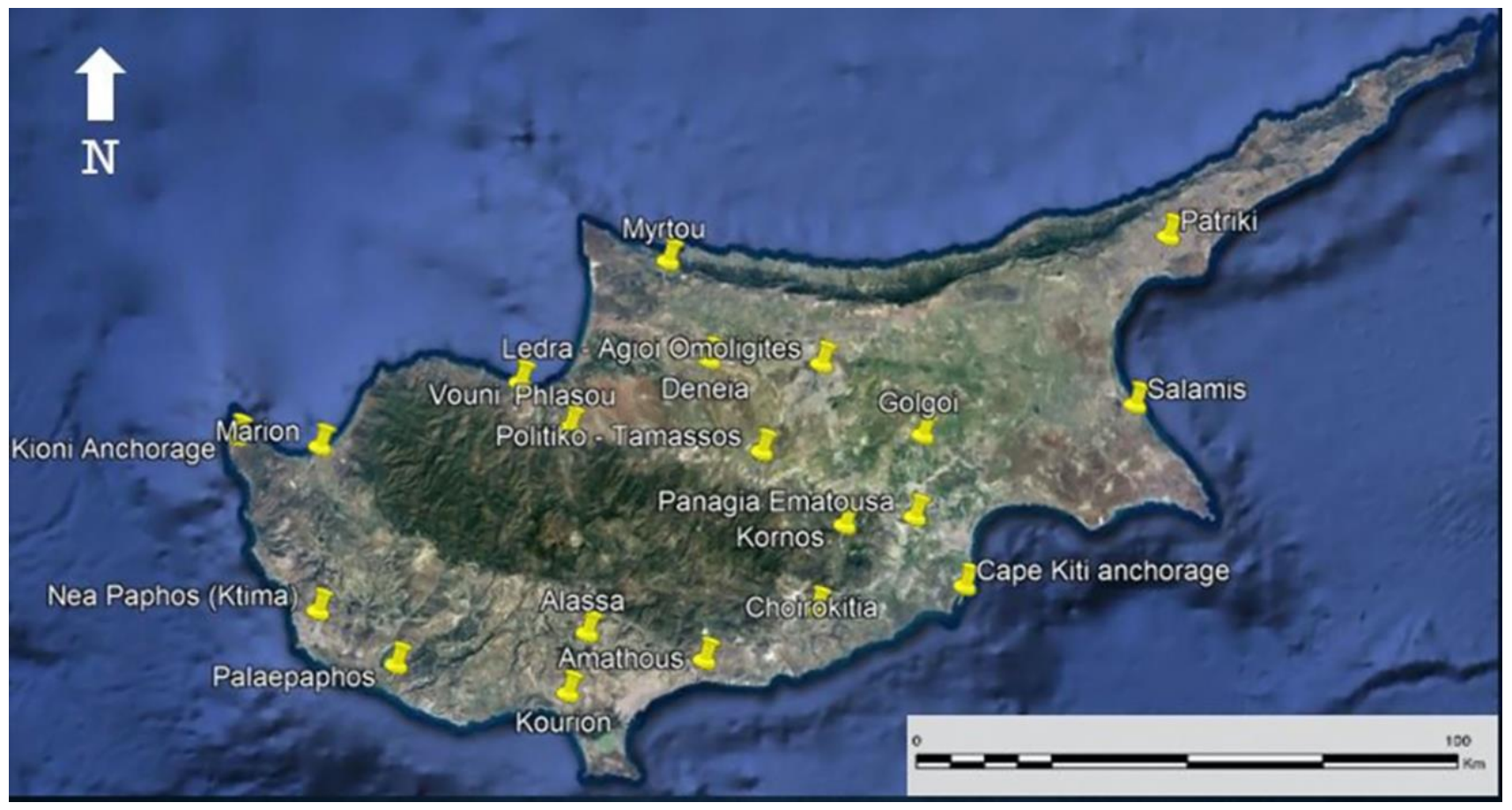

Fig. 5: Cypriot archaeological sites, where Phoenician amphorae were recovered (@ Ch. Christodoulou; Google Earth). 